Article

\title{
Extractive Economies in Material and Political Terms: Broadening the Analytical Scope
}

\author{
Anke Schaffartzik * and Melanie Pichler \\ Institute of Social Ecology (SEC), Alpen-Adria University, A-1070 Vienna, Austria; melanie.pichler@aau.at \\ * Correspondence: anke.schaffartzik@aau.at; Tel.: +43-1-5224000-409
}

Received: 3 February 2017; Accepted: 19 May 2017; Published: 26 June 2017

\begin{abstract}
In order to curb environmental impact, absolute resource use reductions are urgently needed. To reach this goal, multi-scalar synergies and trade-offs in global resource use must be effectively addressed. We propose that better understanding the role of extractive economieseconomies that extract raw material for export-in global resource use patterns is a prerequisite to identifying such synergies and trade-offs. By combining a system-wide environmental accounting perspective with insights from political ecology and political economy research, we demonstrate that (1) the extractivist expansion may be the corollary of reduced immediate environmental impact in the industrialized countries; and (2) the material flow patterns on which this result is based do not suffice to identify the mechanisms underlying extractivist development and its role in global resource use. Our work on extractive economies illustrates that, in order to supply transformative knowledge for sustainability transformation, biophysical and socio-political conceptualizations of society-nature relations must be more strongly integrated within the interdisciplinary sustainability sciences in general and social ecology in particular.
\end{abstract}

Keywords: extractive economies; international trade; material flow accounting; political ecology; social ecology

\section{Introduction}

If we are to have any chance at sustainability transformations, we must reduce our global resource use in absolute terms [1]. Some of the richest countries in the world seem to have made progress towards such reductions: Since the 1970s, countries in Europe, North America, and Asia that industrialized early have experienced stagnating or even declining material resource use [2,3] as reflected in their domestic material consumption (DMC). Under the economy-wide material flow accounting framework, DMC corresponds to material extraction (from agriculture, forestry, and mining) plus material imports minus material exports and covers all the material which an economy integrates into stocks (buildings, infrastructure, and durable goods) and/or either immediately or eventually turns into waste or emissions [4]. When trade plays a dominant role in aggregate material use, the DMC indicator may not offer sufficient information on underlying material flow patterns. What is not directly captured in aggregate material use trajectories is the importance of other countries as sources of raw materials for the environmental progress of the industrialized countries. We postulate that extractive economies which extract raw material for export (as primary goods) [5,6] play a pivotal role in both the stagnation of material resource use in the industrialized countries and in the growth of material use at the global level. By supplying energy- and material-intensive primary resources to the global market, extractive economies enable other countries to concentrate on the addition of value in the secondary or even the tertiary sectors. These sectors tend to be, in direct terms, less materialand energy-intensive and feature high-value output. Imports, rather than domestic extraction, are an increasingly important source of resources for industrialized economies. Extractive economies, 
in contrast, may often be dependent on imports of secondary commodities in meeting their final demand $[7,8]$. The win-win situation in the industrialized countries (experiencing increasing affluence and decreasing resource use) may actually be a lose-lose situation globally (unsustainable income and increasing resource use). As a source of income, the extraction of raw materials, even of 'renewable' biomass, does not offer unlimited growth opportunities: mineral resources are extracted at rates much higher than the rates at which they are naturally replenished while biomass harvest is ultimately limited by available land area (and subject to more confining boundaries when nutrient depletion, water cycles, and environmental impact are taken into account). Yet, the expansion of extractive activities, especially in low- and medium-income countries, is currently being encouraged through a series of political instruments. The European Raw Materials Initiative [9], for example, is aimed at ensuring global supply of raw materials to the European Union while simultaneously encouraging the extraction of raw materials within its borders to improve security of supply [10], not only for minerals but also for biotic resources extracted through agriculture and forestry as expounded in the bioeconomy strategy [11]. The UN holds that extractive industries can ultimately contribute to achieving the Sustainable Development Goals [12,13].

In promoting the extractive activity on which high-consuming and growing economies so heavily depend, Norway, Canada, and Australia are commonly cited as best-practice examples in which significant gains in affluence have been made through expanding extractive activity [13]. All three are both important global suppliers of resources and affluent, economically thriving countries. This general observation as well as our empirical work, with which we also seek to identify to what extent the grounds for this success of a small number of countries may be replicated by other economies, refers to the aggregate national level. Underlying the development at this level of scale are subnational disparities that form part of the staple theory of growth [14], developed in the early 20th century for Canada and considering the role of what we might refer to as subnational core and peripheral regions in raw materials-based growth. While high-income countries in which extraction figures prominently may appear to form a contrast to those countries that exchange low-price primary commodity exports for high-price secondary commodity imports (e.g., Chile, Colombia, Ecuador, Mexico, and Peru [15-18]), it is possible that they share communalities at the subnational level.

The extractivist expansion is potentially a critical barrier to sustainability transitions. In order to come to a better understanding of extractive economies, we propose that it is necessary to (1) identify resource use trajectories of these economies and their role in global resource use patterns and (2) integrate insights from such empirical work within a conceptual framework allowing for the identification of functional mechanisms in this particular form of societal organization of resource use. This is, of course, a tall order and not one we will fulfill with this article. Rather than a full-fledged socio-ecological analysis of extractive economies, we offer an exploration of quantitative material flow data that can be used to characterize extractive economies and a discussion of the 'bridges' to political ecology and political economy research that identify qualitative and space-sensitive understandings of the factors and mechanisms shaping resource use in extractive economies and, by extension, globally. The investigation of resource use trajectories is based on a system-wide perspective and internationally harmonized and comparable indicators [4] which allows us to take synergies and trade-offs across levels of scale into account. The mechanisms underlying these resource use patterns cannot be identified based on quantitative information alone, but require the conceptual, functional understanding that can be gained from solid theoretical underpinning.

We develop a framework of socio-metabolic and socio-economic indicators (biophysical resource extraction, trade, monetary income) and apply it to a global sample of 142 countries in the year 2010. We enrich the emerging biophysical characteristics with those that political ecology and political economy research have identified as potentially important for extractive economies. We propose that social ecology's conceptualization of society as simultaneously socio-cultural and biophysical [19] allows this research field to serve as an umbrella under which the socio-metabolic and political-economic analyses of extractive economies can enter into productive dialogue. This conceptualization of society 
stems from social ecology as developed at the Institute of Social Ecology in Vienna where both authors of this article are based. The editorial for this special issue of Sustainability provides a differentiated discussion of this and other approaches to social ecology.

We discuss major research strands on extractive economies in Section 2 and present a framework of socio-metabolic and socio-economic indicators to quantitatively distinguish different types of extractive economies in Section 3. In Section 4, we present our results-an overview of extractive economies according to material flows and types and national income. In Section 5, we discuss insights from political ecology and political economy research that may enrich the data-driven and quantitative analysis of extractive economies. We propose that by crossing these bridges, we may arrive at a better understanding of the role of extractive economies in the global economy. Such an understanding is essential not only for assessments of this particular development trajectory but is also a prerequisite to evaluating the sustainability of the world's wealthiest economies.

\section{Extractive Economies in the Global Economy}

Our research on extractive economies builds on important previous work, especially from development studies, (ecological) economics, and political ecology, aimed at providing a general narrative on the role of resource provision and consumption in the global economy. After the Second World War, economists noted that, in contrast to countries specialized in manufacturing, primary commodity exporters had experienced deteriorating terms of trade $[20,21]$. The observation of prices for primary commodities declining compared to the prices of secondary commodities in the long-run came to be known as the Prebisch-Singer thesis [22] and influenced the rise of dependency theory [23]. World-systems theory has observed similarly skewed relations between core and periphery countries $[6,24]$. Based on these conceptualizations, the theory of ecologically unequal exchange holds that countries which incur high environmental impacts in the extraction and preliminary processing of raw materials for comparatively low-price exports do not benefit accordingly in financial or material terms $[25,26]$. In development economics, the theory of the "resource curse" has been developed which holds that countries with an abundance of natural resources 'underperform' economically compared to those countries with a lower resource endowment [27-29]. Resource-rich countries may even be more strongly prone to suffer from armed conflict [30]. For our research, the resource curse hypothesis introduces two important points of departure: (1) The entailed critique of assumed socio-economic benefits of extractivist expansion, a pillar of past and current development policy, to which we add the resource use perspective; and (2) The question whether the observed negative impacts of abundant resource endowment are a function of that endowment or perhaps more accurately of mechanisms of societal organization governing the use of resources. For our research, it is additionally noteworthy that the development of the resource curse hypothesis—and even its critique [31,32]! —relied on monetary measurement of natural resources, either as natural resource abundance or dependence (monetary value of primary exports divided by national income) or as natural wealth [33]. More recent research on these interrelated topics (core-periphery relations, ecologically unequal exchange, and the resource curse) has commonly sought to correct this monetary bias. Especially in ecological economics and political ecology, the relationship between physical and monetary flows has been studied in order to determine whether countries benefit from trade or not. Studies empirically testing for patterns of ecologically unequal exchange have not reached agreement in their conclusions [34-39], also because an acceptable monetary amount of revenue for the social and environmental impacts of resource extraction for export cannot be defined [40]. Recently, the research agenda has been developed to more strongly focus on biophysical flows in identifying ecologically unequal exchange and (potential for) environmental conflict (e.g., [40-42]).

Data on biophysical trade flows alone do not sufficiently characterize an extractive economy as socio-economically very different countries such as Australia, Azerbaijan, Bolivia, and Canada would then be grouped together [17]. These countries are net-exporters, and yet, a qualitative distinction between their extractive activities must be made. Within a high-income economy, for example, 
extractive sectors are not necessarily characterized by low capital inputs or lack of skilled labor [43]. Recent contributions from political ecology and political economy have provided differentiated analyses of resource-based development with special emphasis on the access to and control over resources, (transnational) production and consumption networks, and inequality and justice with regard to burdens and benefits of extraction. In Section 5, we further elaborate on these contributions in light of the results of our quantitative analysis of extractive economies.

\section{Defining Extractive Economies in Quantitative Terms}

Our empirical work focuses on insights into extractive economies that can be gained from system-wide material flow data. While this information is pivotal to our understanding of the role of extractive economies in the global economy and global environmental change, we do not expect it to allow for a full-fledged understanding of the observed resource use patterns. On the basis of political ecology and political economy research, we further deliberate these limitations in Section 5.

In material terms, we understand extractive economies to be characterized by the domestic extraction of materials for export and propose two data-driven types of operationalization of this understanding. The first allows us to identify economies in which exports biophysically dominate material use by accounting for more than $50 \%$ of all material input (from domestic extraction and imports). The second isolates countries that are net-exporters, i.e., they export more than they import. The decision-making flow chart in Figure 1 illustrates how we implemented this understanding with the help of standard indicators of material flow accounting: export per direct material input (DMI = domestic extraction plus imports) or physical trade balance (PTB = imports minus exports, i.e., net imports) and domestic extraction (DE) per DMI. Of course, the two categories potentially overlap: Countries can be export-dominated and net-exporters.

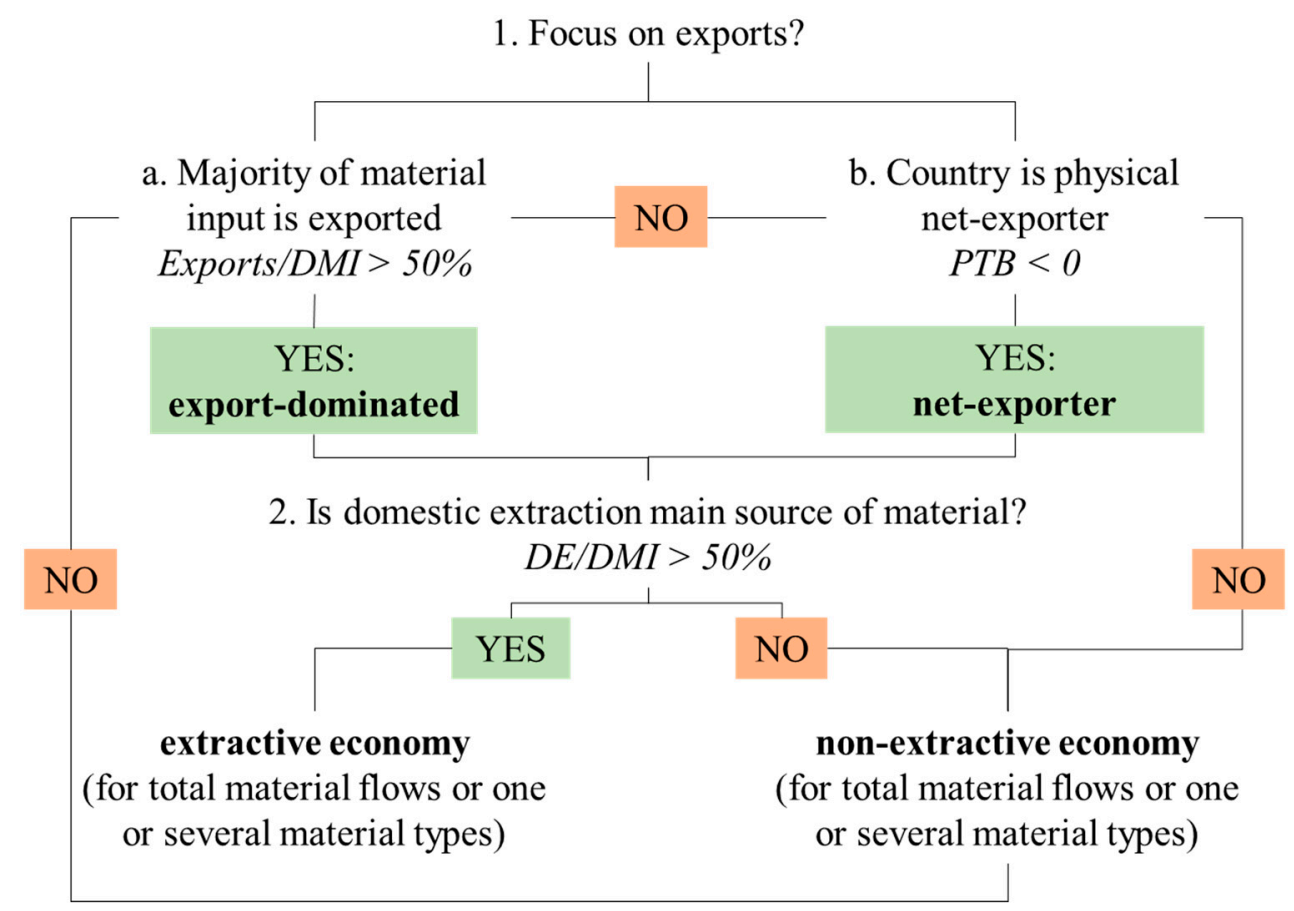

Figure 1. Decision-making flow chart for identification of extractive economy (with regard to total material flows or flows of one or several material types) based on the material flow indicators exports, direct material input (DMI), physical trade balance (PTB), and domestic extraction (DE).

The distinction between export-dominated and net-exporting economies is a priori driven by discernible patterns in the material flow data. Based on potential drivers of such distinct material use patterns, we also expect the two types of extractive economies to be politically and economically 
distinct. The fact that export-dominated economies provide the major share of the material available to them to the global economy may constitute, if underlying production structures are considered, an advantage rather than a loss. Export-dominated economies may be highly efficient in transforming raw materials and primary products into commodities for export, they may strike a beneficial balance in the international division of labor concerning their material inputs, and they may be, in the shortto medium-term, partially protected from international raw material price volatility. For many raw material types, the processing stages that precede export involve so much waste generation that the share of exports in DMI does not rise above $50 \%$. The specific combination of material types, material sources, and technology in export-dominated economies must allow them to process material input into export with comparatively low material losses. For example, processing of crude oil for export involves significantly lower material losses than is the case for copper ore. Resource-rich countries with small populations (e.g., countries with high per capita agricultural land availability) require relatively less of their resources for the consumption of their population (e.g., agricultural biomass) than do countries that are more populous. Export-dominated economies may additionally be extractive economies of the second degree in that they not only process domestically extracted raw materials but also import primary products for export. Especially the high-income extractive economies tend to be importers of primary products for further processing. By re-exporting materials that have already undergone some degree of processing, economies require relatively less material and energy input in the production process than economies that rely exclusively on domestically extracted raw material. In the international division of labor, they act not only as resource suppliers but also rely on extractive sectors in other countries. This mixed sourcing of raw materials and primary products, however, may allow them to benefit from international price volatility for primary commodities and offer some degree of protection from the so-called "specialization trap" [44,45].

While we expect very few economies to fulfill the export-dominated criteria, many more countries and even entire country groupings and regions are known to be biophysical net-exporters [3]. Net-exporters are global suppliers of material and provide more to the international markets than they require from them. From the national perspective, these net-exports often constitute an important source of income. In the international context, however, net-exporters may be relatively small contributors to global supply, offering them little leverage and making them economically and politically vulnerable as a result of their own specialization in extraction and production for export.

In order to be considered as extractive economies, both the export-dominated countries and the net-exporters had to domestically extract the majority of the total material available to them (DE/DMI $>50 \%$ ). While, as previously stated, we were interested in considering as extractive those economies that complement resource extraction with the import of primary commodities for further processing, we did not want to include countries relying chiefly on the re-export of imported materials as extractive. Countries may, for example, specialize in the production of high-grade steel for export but not engage in extraction of iron ore. Instead, they import iron concentrate for further processing. While this constitutes an interesting form of international exchange, it does not, in our understanding, characterize an extractive economy.

We analyzed exports, net imports, DE, and DMI and the relationships among them as totals as well as for material types to allow for economies behaving in an extractive manner with regard to one or several types of materials but not with regard to others. The indicators were processed in physical units (tonnes) for a global sample of 142 countries in the year 2010. The underlying material flow data were extracted from the database maintained at the Institute of Social Ecology, Vienna [3]. This view of the global economy in 2010 affords the advantage of data coverage for a large number of countries. By choosing a static perspective, we are able to gain insight into resource patterns at one point in time which can be grasped through the conceptualization we propose. While this provides us with the opportunity to test and discuss the potential and limits of our definition of extractive economies, it does not take development pathways into account. They are not addressed within the scope of this 
article but we do consider such pathways (e.g., of decreasing or increasing material extraction, exports, income) to be very important in advancing research on extractive economies.

We based our primary definition of extractive economies on purely biophysical indicators in order to be able to identify those economies that dominantly exported domestically sourced resources. Of course, there is a 'hidden' socio-economic component to these indicators in the sense that they do not reflect purely geomorphological and/or climatic endowment with resources but also the socio-economic feasibility of their extraction and trade. Additionally, past resource depletion determines whether countries in 2010 meet the criteria we have defined.

We wanted to determine whether the resource use patterns of extractive economies, defined according to biophysical criteria, coincided in any way with economic performance. In a first approach, we used gross national income (GNI) expressed in 2010 US dollars according to the Atlas method [46]. Based on the per capita income level, we further distinguished countries and country groupings by four income categories: high income (above 12,275 US \$/cap), upper middle income (above 3976 US \$), lower middle income (above 1005 US \$/cap), and low income [47].

Previous socio-ecological studies on the role of trade for resource use patterns have commonly relied on the physical trade balance ( $\mathrm{PTB}=$ imports - exports), an indicator derived from material flow accounting [4]. Countries, regions or country groupings have been distinguished according to whether they are net-suppliers (i.e., net-exporters) or net-consumers (i.e., net-importers) of materials [34,48]. Extractive economies were generally characterized by a negative PTB, i.e., as net-exporters. However, even countries that are not physical net exporters may be extracting/producing for foreign demand. It has been shown for the case of Chile, for example, that a significant share of the country's very high level of material consumption consists of waste rock extracted during mining of metals for export in a concentrated or pure form $[49,50]$. This waste rock itself is not exported and yet must be extracted so that copper may be exported. In order to generate a more detailed picture of international trade patterns, the material flow accounting (MFA) community is currently developing methods which allow for the quantification of the amount of material used for the production of exports (and hence not used to satisfy domestic final demand). These upstream material requirements include the mass of the trade flows upon crossing the border as it is traditionally covered in MFA (see [51]) and additionally allocate the material used in the production of exports but not incorporated in the flow itself. Accounting for upstream material requirements currently relies on approximations via monetary input-output data which reflect the structure of production and consumption [52] because data in physical units denoting the material use for production of exports are not available [53]. In the study of extractive economies, however, information on material and economic trade patterns is needed independently so that interrelations between both types of development may be considered. This criterion is not met by upstream material accounts based on monetary input-output tables [53], for a discussion of the implications, also see [54]. We have therefore used material flow data from biophysical accounting for our analysis.

\section{Comparing Extractive Economies}

In the following, we apply our two-part, data-driven definition of extractive economies (Figure 1) to our data sample to provide a quantitative distinction among extractive economies, which can be productively discussed in light of political ecology and political economy advances.

\subsection{Extractive Economies in Global Trade by Income Groups}

Material flow data aggregated by national income shows that some of the world's richest countries rely on the rest of the world (home to the majority of the global population) to supply them with natural resources. Since the Second World War, early industrializers in Europe, North America, and Asia have been, as a country grouping, net-importers of material. Since the 1970s, fossil fuels (mainly coal, petroleum, and natural gas) have accounted for more than half of the imports of the early industrializers [3]. With the exception of Asia in the most recent decades, all other world 
regions (Sub-Saharan Africa, Middle East and North Africa, Latin America and the Caribbean, and the countries which emerged from the dissolution of the Soviet Union) at all other points in time between 1950 and 2010 were net-exporters of material.

In approaching the economic performance of extractive economies, we grouped countries in 2010 according to their income level and calculated the PTB by material categories for each country grouping. The early industrializers largely coincide with the high-income countries that were the grouping with the highest net imports in 2010: Their imports exceeded their exports by 500 million tons (Figure 2). In 2010, the high-income countries (dominated, for most metals, by Australia and Canada) accounted for $25 \%$ or more of the global extraction of iron ore, bauxite, zinc, lead, gold, ilmenite, and rutile [3]. While the high-income countries were net-exporters of metals and biomass (from agriculture and forestry), they relied very strongly on imports of fossil fuels (mainly coal, oil, and natural gas) and, in much lower amounts, of construction minerals (such as sand and gravel), industrial minerals (e.g., fertilizers), and complex multi-material products that consist of several different types of material. By displaying trade flows by income groupings, we can determine that these high net imports stem from the middle-income countries. Fossil fuels flow into the high-income countries from, for example, Nigeria, Yemen, and Indonesia. Net-exports of metals and biomass flow from high-income (e.g., Australia for metals, many European countries for biomass) and lower-middle-income countries (especially in Sub-Saharan Africa and Southeast Asia as well as India, for example) to the upper-middle-income countries (among which China has become an important importer). Overall, the middle-income countries supplied approximately 900 million tons of material to the global economy in 2010, with the larger share stemming from the upper-middle-income countries. The low-income countries are characterized by low integration into the global economy and their net imports are approximately one tenth of the net imports of the high-income countries.

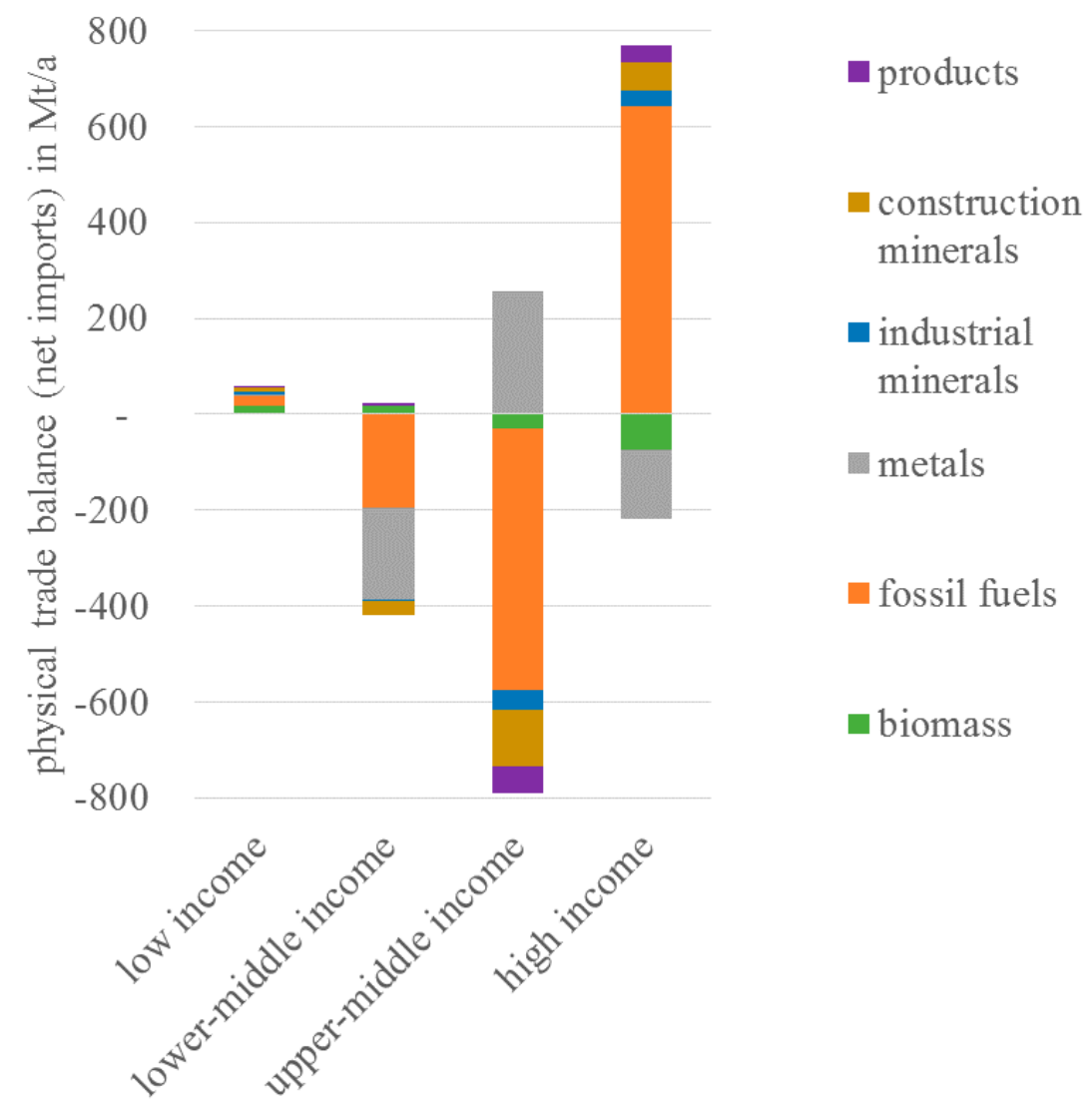

Figure 2. Physical trade balances (imports minus exports) in Megatons per year (Mt/a) by material categories for income-based country groupings [47]. Source of material flow data: [3]. 


\subsection{Extractive Economies' Material Flows and Income}

We found a small and inhomogeneous group of seven countries to meet the criteria for export-dominated extractive economies (Table 1). The seven countries were Norway, the Republic of the Congo, Qatar, Trinidad and Tobago, Oman, Kuwait, and Australia. Given the size of this group and the exogenously defined cut-off threshold (50\%) in our extractive economies definition (Figure 1), we do not propose to conduct a systematic analysis of this result. What does stand out, however, is the dominant role of domestic sources in fossil energy supply for all of these countries (and for those countries approaching but not meeting the 50\% exports/DMI criterion). In these countries, more than $80 \%$ of fossil fuel DMI stems from domestic extraction; in some cases, this share approaches $100 \%$. All export-dominated extractive economies were net-exporters of fossil fuels and fossil fuels were the most important export flow in monetary terms. With the exception of Australia, 50\% or more of monetary exports of these countries consisted of crude and refined petroleum and petroleum gas [55]. For Australia, coal contributed significantly to monetary fossil energy carrier exports and this material category was closely followed by metals (especially iron ore but also copper) in monetary terms. This material evidence supports the assumption we initially made with regard to the efficiency with which export-dominated economies must transform extracted raw materials into exports. This efficiency is, in general, higher for fossil fuels than, for example, for metals. In addition, the availability of (comparatively cheap and stably priced) energy may be a decisive factor in biophysically sustaining export-dominated economies. Together, these seven economies accounted for almost $14 \%$ of all physical exports and for less than $1 \%$ of the world population. They generated almost $3 \%$ of the global income, and all but one (the Republic of the Congo) were high-income countries; their average income in 2010 amounted to over 43,000 US \$/cap (with 12,275 US \$/cap being the threshold for high income that year). A small number of countries appear to be thriving economically based on the extraction of high amounts of resources for export coupled with domestic fossil energy availability. This extractivism-income link, however, neither applies to the majority of countries engaged in extractive activity nor does it represent a trajectory that can be easily replicated as it appears to rely, at least in part, on the biophysical availability of fossil fuels and the economic feasibility of their extraction.

Table 1. Overview of extractive economies in 2010. Share in global exports indicates percentage of global biophysical exports in each material category originating from the group of countries classified as extractive with regard to that material. Income level distinguishes high (H), upper middle (UM), and lower middle (LM) income. None of the groups of economies defined as extractive experienced average low income as per the World Bank [47] definition. Sources of data: [3,46].

\begin{tabular}{|c|c|c|c|c|c|c|c|c|}
\hline & \multicolumn{4}{|c|}{ Export-Dominated } & \multicolumn{4}{|c|}{ Net-Exporters } \\
\hline & n(1) & $\begin{array}{c}\text { Share in } \\
\text { Global } \\
\text { Exports }\end{array}$ & $\begin{array}{c}\text { Average } \\
\text { Income } \\
\text { (GNI/cap) }\end{array}$ & $\begin{array}{l}\text { Average } \\
\text { Income } \\
\text { Level }\end{array}$ & $n(2)$ & $\begin{array}{l}\text { Share in } \\
\text { Global } \\
\text { Exports }\end{array}$ & $\begin{array}{l}\text { Average } \\
\text { Income } \\
\text { (GNI/cap) }\end{array}$ & $\begin{array}{c}\text { Average } \\
\text { Income } \\
\text { Level }\end{array}$ \\
\hline Total & 7 & $13.5 \%$ & 43,228 & $\mathrm{H}$ & 49 & $59.0 \%$ & 6813 & UM \\
\hline Biomass & 1 & $0.1 \%$ & 36,670 & $\mathrm{H}$ & 57 & $68.3 \%$ & 10,136 & UM \\
\hline Fossil Fuels & 25 & $52.0 \%$ & 6787 & UM & 38 & $76.0 \%$ & 6110 & UM \\
\hline Metals & 11 & $47.1 \%$ & 3359 & LM & 28 & $62.6 \%$ & 4176 & UM \\
\hline Industrial Minerals & 14 & $32.3 \%$ & 10,673 & UM & 26 & $61.0 \%$ & 7484 & UM \\
\hline Construction Minerals & 3 & $3.8 \%$ & 8301 & UM & 45 & $78.3 \%$ & 7150 & UM \\
\hline
\end{tabular}

Many more countries (49) were net-exporters of total materials. This group of extractive economies accounted for almost $60 \%$ of total global physical exports in 2010, approximately $24 \%$ of the population, and 19\% of global income. With an average income of 6813 US \$/cap (less than 16\% of the average income of export-dominated extractive economies), this country grouping could be classified as upper middle income. Within this group of global suppliers of material resources, those countries with higher national income tend to have higher net exports per capita (Figure 3). Countries that structurally dedicate the resources available to them to export appear to profit economically if they are able to 
export relatively more of those resources. Accordingly, those extractive economies with the highest per capita net exports are also those with the highest average income. Given this relationship, the low level of integration of low-income economies into global material trade (Figure 3), may play a functional role in their extractivism-income link. The expansion of primary exports, however, cannot be considered as the key to sustainable economic growth: the possibility for expansion is limited based on resource endowment (location and size of the country) and extraction and processing capabilities. While the latter can be improved to some extent through investment, the former is subject to physical limits and to trade-offs with other forms of land use. At the same time, high average income may be associated with high domestic inequality in income (see Section 5.3). Therefore, the progression of countries from low income and low exports to high income and high exports in Figure 3 cannot be understood as a potential development trajectory for an individual country.

The relationship between exports and GDP is a long-standing topic in development economics, with the identified positive correlation (of the monetary indicators) constituting one of the pillars of export-led development policies [56,57]. As opposed to the analysis based purely on monetary indicators, our results allow us to make two important distinctions: (1) the positive correlation between income and physical exports holds true only for net-exporting countries, i.e., cannot be verified for a general relationship between exports and income; and (2) among the net-exporters, any possible contribution of exports to income also comes at an environmental cost (more material must be exported).

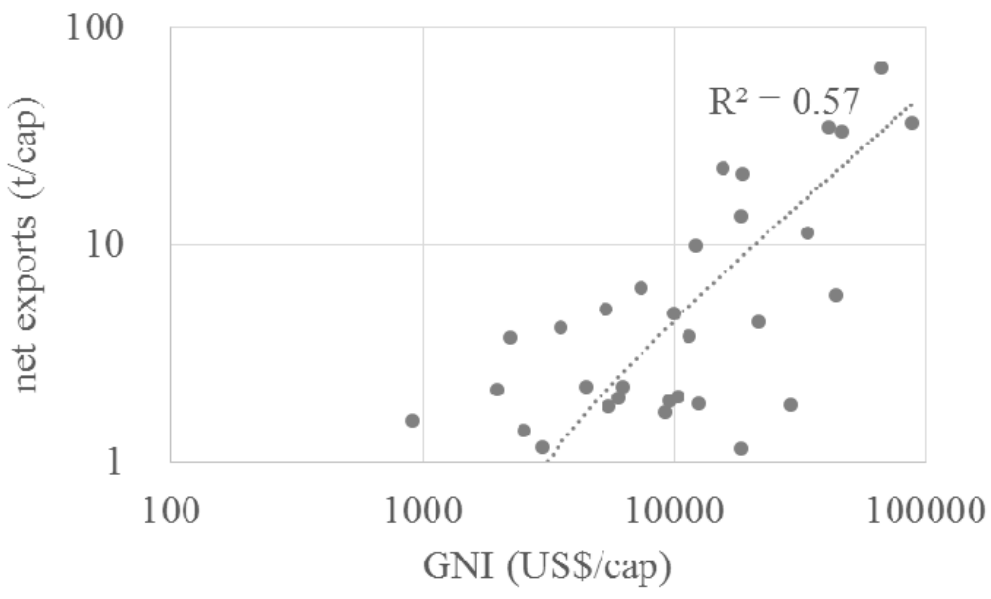

Figure 3. Gross national income (GNI) per capita and net exports in tons per capita (t/cap) for 49 extractive economies (export-dominated and net-exporters) in 2010. The linear relationship is highly significant $(p<0.001)$. Please note that both axes are logarithmically scaled. Sources of data: $[3,43]$.

\subsection{Extractive Economies by Material Types}

The number of export-dominated countries is very small for biomass (Iceland) and construction minerals (Norway, Bhutan, and the Bahamas) and stands in strong contrast to the number of net-exporters for these same materials: 57 countries for biomass, corresponding to over $68 \%$ of global biomass exports, and 45 countries for construction minerals (78\% of global exports). Most countries domestically consume the bulk of biomass and construction minerals extracted. This does not necessarily mean that the use of these materials is directly driven by domestic final demand: For example, construction minerals may be used in factories for the production of exports and grazed biomass and fodder crops may be used to feed livestock and produce animal products for export. For fossil fuels, 25 countries were export-dominated and 38 were net-exporters. Fossil fuel extractive economies accounted for more than $\frac{3}{4}$ of all fossil fuel exports in 2010. Countries of all income categories were represented in this group with an average income between 6000 and 7000 US \$/cap corresponding to upper middle income. For metals, 11 economies were export-dominated and 28 were 
net-exporters. Eleven countries accounted for almost $50 \%$ of global metal exports, the 28 net-exporters accounted for approximately $15 \%$ more. In spite of their significant contribution to global supply, the export-dominated economies for metals feature the lowest average income (below 3500 US \$/cap, lower middle income) out of all the groupings presented in Table 1. In contrast to the extractive economies for all other material types, the average income is lower here for the export-dominated economies than for the net-exporters. For metals, in particular, the amount of material loss (waste rock) between extraction and export can be very large; the metal content of extracted ore may be below $1 \%$. For industrial minerals, the contribution to global exports is more evenly divided between the extractive economies with the 14 export-dominated countries contributing $32 \%$ and the 26 net-exporters contributing slightly less than twice that share $(61 \%)$.

The positive relationship between income and net exports for total material flows (Figure 2) does not hold true for all of the material categories. Even at the very high level of aggregation by five material categories, which resources a country extracts for export makes a difference in that country's economic performance. A positive correlation between income and per capita net exports was only found for fossil fuels $\left(R^{2}=0.47, p<0.001\right)$. For all other materials, the analysis did indicate a positive relation $(R>0)$ but with a low goodness-of-fit and/or low significance of the determined relationship.

\section{Insights from Political Ecology and Political Economy}

The quantitative economic and material flow data provides important insights on extractive economies in aggregate terms of inhomogeneous material categories and at the national level. To better understand the potential prospects and risks of extractive economies, we bring these results into dialogue with insights from political ecology and political economy research. These case studies have closely examined extractive activity for specific resources and countries as well as at different scales to gain insight into the role of political and economic mechanisms that shape extractive economies. From the wealth of theoretical underpinning and empirical evidence applicable to our research on extractive economies, we have selected two fundamental mechanisms by which resource extraction and use is societally organized: (1) the access to land as a precondition to any type of extractivist expansion; and (2) the integration of the economy in question in transnational networks of production and consumption as decisive for the role which export-led extraction may play. Both these mechanisms are related to inequality and justice with direct implications for the distribution of benefits and burdens associated with extractivist development.

\subsection{Contested Access to and Control Over Land and Resources}

Extractive activity requires access to and control over territories in order to extract one particular material or resource. Vast areas of land are typically appropriated; water and energy constitute other important inputs. Political ecology research has identified the pivotal role of control over land in extractive economies [58-61]. Extractive industries require exclusive control over land that often excludes existing users and uses from these lands. The state and power relations within (state) institutions play a crucial role in defining and formalizing exclusive property rights which precede the extraction of resources from specific territories (both for state and private companies) [62]. The resulting land-use competition [63] or competing claims to land [59] increasingly becomes manifest in conflicts over access to land, especially at the resource-use frontier where new claims are established $[5,64,65]$. Our study of material flows and economic indicators would lead us to expect potential for conflict wherever extraction expands [66], even in the high-income extractive economies. Comprehensive research into socio-ecological conflicts as represented by the Environmental Justice Atlas (compiled under the European FP7 project EJOLT (Environmental Justice Organizations, Liabilities and Trade): http:/ / ejatlas.org/) empirically documents that the link is not as straight-forward as 'more extraction, more conflict'. Instead, manifest conflicts depend on specific power relations and institutional orders in the respective countries as well as on the specific integration of countries or local extraction sites in the world market $[67,68]$. Conflicts over water in the drought-plagued Murray-Darling basin in 
southeastern Australia, for example, have been carried out chiefly over economic issues, between farmers and miners and between governments at the sub-national level [69,70]. In many countries of the global South, in contrast, claims to subsistence and indigenous lands have pitted actors with much greater disparity in power against each other (also see Section 5.3). The recent opening of the economy for the exploitation of natural resources in Myanmar, for example, has given rise to resistance against land enclosure in the ethnically diverse uplands of the country [64]. Similarly, the rapid expansion of oil palm plantations in Indonesia has led to conflicts with indigenous peoples who challenge the territorialization and commodification of their lands [59]. What is observed as environmentally unequal exchange (Section 2) based on international inequalities between trade partners, may be directly linked to inequalities at the subnational level with regard to the access to resources and hence also the power to make decisions with regard to their use. In order to operationalize such inequality in biophysical resource use, aggregate national indicators do not suffice and current developments towards subnational or even spatially explicit data collection are imperative.

Through its role in securing access to and control over land, the state plays an important role in how and by whom rents from the extraction of natural resources are obtained. Governments at different levels may see their role in supporting extractive industries' access to land if rents, secured in essence by access to that land, constitute an important source of income for the national or regional economy [71,72]. This observation is potentially tied to one we have made based on material flow data: Countries that domestically extract and import raw and semi-processed materials for further processing before export are less dependent on rent as a source of income than those countries with no internal processing capacities. We suggested that, in general, the degree to which countries are able to build economic complexity surrounding their extractive industries may play an important role in national income. In light of the political ecology and economy research, we further propose that the share of rents in total national income would also play a role in how access to land is governed. The observed resource curse (Section 2) may depend less strongly on the endowment with natural resources (even if this were physically and not only monetarily captured) and more on how and to what end available resources are governed.

\subsection{Transnational Production and Consumption Networks}

In material terms, we were able to distinguish countries concentrating on the extraction of resources for export from those countries specializing in the extraction of individual material types (e.g., biomass, fossil fuels, metals). High-income extractive economies tend not to specialize in the extraction of only one type of material, although fossil fuels tend to be among the materials extracted (Section 4.2), and exhibit a high to intermediate economic complexity index [55]. Political economy research has linked the focus on the extraction of a small number of specific resources to the "specialization trap", in which countries are especially vulnerable to fluctuating world market commodity prices and ensuing boom-and-bust dynamics $[44,45]$. The reasons for such specialization may partially lie in resource endowment and can additionally be found in extractive industry's role in global value chains and world market integration [73,74]. Investment, governance, and ownership patterns in transnational production and consumption networks strongly influence the role of the extractive sector within the national economy. The national or regional advantage of the extractive sector may, therefore, not only depend on power relations between individual nation states but also on the relational ways in which companies, states, workers, and consumers are incorporated in production networks that transgress national boundaries [74]. Depending on these transnational relations, extractive sectors, especially in the Global South, tend to develop enclave economies. These enclaves are characterized by weak linkages between large-scale investments in extractive sectors and local companies or the national economy at large and are often led by international or foreign capital [74-76]. National governments and institutional structures may play a decisive role in creating linkage effects and contributing to the (economic) success (or lack thereof) of the extractive economy. An analysis of extractive economies has to consider the network of production and consumption to which an extractive industry contributes at 
the international (bilateral trade relations) and the transnational level (networks of corporations and businesses not apparent at the aggregate national scale), i.e., the conflicting interests and dependencies of companies, states, and other transnational players [74].

At the national level at which material flow data are currently available, we were able to identify the role of economies as global suppliers or consumers of resources. In addition, patterns in material extraction began to emerge, possibly providing some indication of biophysical manifestations of economic integration of the extractive activity. We found, for example, that extractive economies based on a mix of materials in their exports tended to feature higher income if they also extracted fossil fuels. The associated access to comparatively cheap energy for the extractive industries as well as for further processing may be decisive in the degree to which countries can economically benefit from their extractive activities. Yet, based on aggregate national material flow data, we cannot draw definite conclusions as to the integration of the extractive activity into the economy, which may be just as influential as the question of economic complexity.

\subsection{Inequality and Justice}

Linked to the access to and control over resources and the role of extractive sectors in (transnational) production and consumption networks are questions of inequality and justice [77]. This strand of research has centered on who stands to benefit economically and socially from resource extraction and who carries the socio-ecological costs, including, for example, pollution, loss of land, or health impacts [78].

Irrespective of average national income, extractive economies may face particular challenges with regard to intra-national inequality because increasing affluence at the national level (e.g., through the increase of rents from the export of primary commodities) is not necessarily linked to an equal share of this affluence by all social groups $[71,76,79,80]$. Even in countries that attempted to redirect increasing rents of natural resource exports towards marginalized groups in recent years (e.g., Ecuador, Bolivia, Argentina), the redistributional effects have remained marginal. In many cases, social policies were oriented towards conditional cash transfer programs to combat extreme poverty but have not taken up more structural efforts to reform the highly unequal tax system or land ownership structures that benefit the wealthy sectors of society [72].

Whereas political economy research has analyzed inequality and justice mainly from an economic and monetary perspective, political ecology has highlighted the political dimensions of justice [81,82]. In a multi-dimensional perspective, political representation and cultural recognition are incorporated in the analysis of socio-ecological justice with regard to resource extraction. Political representation asks who is included in decision-making processes and how rules and procedures for extractive economies are set. Cultural recognition demands a sensitivity towards alternative ways of living and forms of knowledge (e.g., subsistence farming, indigenous production systems) that challenge extractive sites and may be missed in economic analyses of inequality [66,81].

Systematically considering inequality along its environmental, social, and economic dimensions and in light of its sustainability implications and underlying drivers across levels of scale constitutes an important research frontier for social ecology. This frontier promises to be especially productive not only with regard to the specific role of inequality in extractive economies but also more generally in aiding social ecology to contribute to transformative knowledge for sustainability transformation.

\section{Conclusions: Socio-Ecological Research on Extractive Economies}

Starting from a data-driven socio-metabolic approach, this article has presented a comparison of extractive industries in quantitative terms. We found that the richest countries in the world have relied on the rest of the world to supply them with raw materials although they seem to have experienced declining material use in national extraction since the 1970s. Fossil fuels comprise the most important imports of primary commodities for these high-income countries. We distinguished between export-dominated countries that export more than $50 \%$ of their material input and net-exporters 
that provide the world market with more raw material than they import. Fossil fuels stand out, as all export-dominated countries are able to extract fossil fuels domestically. For most of them, fossil fuels are also the major export product. Whereas extractive economies are not necessarily linked to high or low levels of average national income, there are some interesting correlations. For countries that are net-exporters with regard to their total exports and imports, there is indeed a positive correlation with average national income, whereas metals export-dominated countries tend to exhibit comparatively low average income. For metals, in particular, the amount of material loss (waste rock) between extraction and export can be very large which might be an explanation for this pattern. By considering extractive economies in their aggregate, biophysical dimensions at the national level, we cannot conclude what causes the (economic) success or failure of such economies. We demonstrate that there are insights to be gained from this particular socio-ecological take on the extractive economy that provide potential for synergy with the political economy and political ecology research on associated socio-economic and political-institutional arrangements.

First, case studies have demonstrated how the question of access to and control over resources is decisive for biophysical availability of resources and emerging resource use patterns as well as for potential and manifest conflicts arising from extractive industries. Second, research on global value chains has highlighted the importance of transnational networks of production and consumption that transgress the national scale of analysis and have decisive consequences for the national and regional advantages (or lack thereof) of extraction sites. Overall, where extractivism is associated with higher average national income (as may be the case in the net-exporting countries), research on inequality and justice has shown that this rise in income is not necessarily linked to an equal share in this affluence by all social groups. Specific institutional arrangement and power relations matter, and monetary economic redistribution has to be accompanied by political and cultural dimensions of justice. Observed manifestations of the patterns in international resource trade such as the resource curse hypothesis and ecologically unequal exchange provide conceptual entry points for the type of integrated qualitative and quantitative research which we propose. At the same time, that research has the potential for further illuminating these concepts, especially by considering why they appear analytically valid yet not universally applicable. Here, the insights to be gained from material flow data on the composition of resource extraction and use constitute examples of how the mutual links between resource use patterns and their societal organization shape country-level development.

Any development trajectory based on the high and growing exploitation of natural resources will ultimately run into physical limits. These will initially be observed economically as rising costs of extraction but are ultimately biophysical in nature. In fact, some of the early industrializers have developed from extractive economies towards a stronger focus on the secondary and tertiary sectors. In the United Kingdom, for example, the domestic extraction of iron ore for the country's signature steel industry has long ceased to be economically viable. Instead, steel production has relied on imports of ores and concentrates. As, however, some of the world's most important extractive economies for iron began increasingly focusing on further processing of steel and on newly emerging markets, imports as a source of supply for the United Kingdom's industry dwindled. This 'other side of the coin' must be considered alongside the more common narrative of global glut and falling prices affecting the industrial motherland's ability to compete internationally in what was once one of its prime commodities $[83,84]$. Just as secondary processing relies on the extraction of primary material elsewhere, so does the tertiary sector rely to some extent on secondary (and by extension primary) economic activities. Continued growth, no matter which of the areas of the economy it relies on, is therefore ultimately unsustainable.

The development of an extractive economy occurs simultaneously in biophysical and in socio-political terms. As a result, research is required which allows us to "address social and natural structures and processes on an equal epistemological footing". Social ecology offers a conceptual framework of society-nature relations in which "human social and natural systems interact, coevolve over time and have substantial impacts upon one another" [19]. Within such a framework, the results 
on extractive economies' material flows and their socio-political arrangements must be further made mutually meaningful and applied in integrated socio-ecological research on extractive economies.

Author Contributions: A.S. analyzed the data, M.P. reviewed the literature, A.S. and M.P. wrote the paper.

Conflicts of Interest: The authors declare no conflict of interest.

\section{References}

1. Akenji, L.; Bengtsson, M.; Bleischwitz, R.; Tukker, A.; Schandl, H. Ossified materialism: Introduction to the special volume on absolute reductions in materials throughput and emissions. J. Clean. Prod. 2016, 132, 1-16. [CrossRef]

2. Wiedenhofer, D.; Rovenskaya, E.; Haas, W.; Krausmann, F.; Pallua, I.; Fischer-Kowalski, M. Is there a 1970s Syndrome? Analyzing Structural Breaks in the Metabolism of Industrial Economies. Energy Procedia 2013, 40, 182-191.

3. Schaffartzik, A.; Mayer, A.; Gingrich, S.; Eisenmenger, N.; Loy, C.; Krausmann, F. The global metabolic transition: Regional patterns and trends of global material flows, 1950-2010. Glob. Environ. Chang. 2014, 26, 87-97. [CrossRef] [PubMed]

4. Fischer-Kowalski, M.; Krausmann, F.; Giljum, S.; Lutter, S.; Mayer, A.; Bringezu, S.; Moriguchi, Y.; Schütz, H.; Schandl, H.; Weisz, H. Methodology and Indicators of Economy-wide Material Flow Accounting. J. Ind. Ecol. 2011, 15, 855-876. [CrossRef]

5. Bebbington, A. Social Conflict, Economic Development and the Extractive Industry: Evidence from South America; Routledge: London, UK, 2011.

6. Bunker, S.G. Underdeveloping the Amazon: Extraction, Unequal Exchange, and the Failure of the Modern State; University of Chicago Press: Chicago, IL, USA, 1985.

7. Eisenmenger, N.; Giljum, S. Evidence from societal metabolism studies for ecological unequal trade. In The World System and the Earth System: Global Socioenvironmental Change and Sustainability since the Neolithic; Hornborg, A., Crumley, C.L., Eds.; Left Coast Press: Walnut Creek, CA, USA, 2007; pp. $288-302$.

8. Schaffartzik, A.; Mayer, A.; Eisenmenger, N.; Krausmann, F. Global patterns of metal extractivism, 1950-2010: Providing the bones for the industrial society's skeleton. Ecol. Econ. 2016, 122, 101-110. [CrossRef]

9. European Commission. The Raw Materials Initiative. Meeting Our Critical Needs for Growth and Jobs in Europe; European Commission: Brussels, Belgium, 2008.

10. European Commission. Communication from the Commission to the European Parliament, the Council, the European Economic and Social Committee and the Committee of the Regions for a European Ind. Renaissance; European Commission: Brussels, Belgium, 2014.

11. European Commission. Innovating for Sustainable Growth. A Bioeconomy for Europe; Publications Office of the European Union: Luxembourg, 2012.

12. United Nations. Transforming Our World: The 2030 Agenda for Sustainable Development; United Nations: New York, NY, USA, 2015; Volume A/RES/70/1.

13. UNDP Helen Clark: Speech at the Event "Extractive Industries and the Sustainable Development Goals-Enhancing Collaboration for Sustainability". Available online: http://www.undp.org/ content/undp/en/home/presscenter/speeches/2015/09/27/helen-clark-speech-at-the-event-extractiveindustries-and-the-sustainable-development-goals-enhancing-collaboration-for-sustainability-.html (accessed on 10 January 2017).

14. Watkins, M.H. A Staple Theory of Economic Growth. Can. J. Econ. Political Sci. 1963, 29, 141-158. [CrossRef]

15. Russi, D.; Gonzalez-Martinez, A.C.; Silva-Macher, J.C.; Giljum, S.; Martinez-Alier, J.; Vallejo, M.C. Material Flows in Latin America. J. Ind. Ecol. 2008, 12, 704-720. [CrossRef]

16. Gonzalez-Martinez, A.C.; Schandl, H. The biophysical perspective of a middle income economy: Material flows in Mexico. Ecol. Econ. 2008, 68, 317-327. [CrossRef]

17. Vallejo, M.C. Biophysical structure of the Ecuadorian economy, foreign trade, and policy implications. Ecol. Econ. 2010, 70, 159-169. [CrossRef]

18. Vallejo, M.C.; Pérez Rincón, M.A.; Martinez-Alier, J. Metabolic Profile of the Colombian Economy from 1970 to 2007. J. Ind. Ecol. 2011, 15, 245-267. [CrossRef] 
19. Fischer-Kowalski, M.; Weisz, H. The Archipelago of Social Ecology and the Island of the Vienna School. In Social Ecology. Society-Nature Relations across Time and Space; Haberl, H., Fischer-Kowalski, M., Krausmann, F., Winiwarter, V., Eds.; Springer International Publishing: Cham, Switzerland, 2016; Volume 5, pp. 3-28.

20. Prebisch, R. The Economic Development of Latin America and Its Principal Problems; United Nations Economic Commission for Latin America: New York, NY, USA, 1949.

21. Singer, H.W. The Distribution of Gains between Investing and Borrowing Countries. Am. Econ. Rev. 1950, 40, 473-485.

22. Harvey, D.I.; Kellard, N.M.; Madsen, J.B.; Wohar, M.E. The Prebisch-Singer Hypothesis: Four Centuries of Evidence. Rev. Econ. Stat. 2010, 92, 367-377. [CrossRef]

23. Frank, A.G. Latin America: Underdevelopment or Revolution: Essays on the Development of Underdevelopment and the Immediate Enemy; Monthly Review Press: New York, NY, USA, 1969.

24. Wallerstein, I.M. World-Systems Analysis: An Introduction; Duke University Press: Durham, NC, USA, 2004.

25. Hornborg, A. Towards an ecological theory of unequal exchange: Articulating world system theory and ecological economics. Ecol. Econ. 1998, 25, 127-136. [CrossRef]

26. Muradian, R.; O'Connor, M.; Martinez-Alier, J. Embodied pollution in trade: Estimating the "environmental load displacement" of industrialised countries. Ecol. Econ. 2002, 41, 51-67. [CrossRef]

27. Sachs, J.D.; Warner, A.M. Natural Resource Abundance and Economic Growth; National Bureau of Economic Research: Cambridge, MA, USA, 1995.

28. Ross, M.L. The Political Economy of the Resource Curse. World Politics 1999, 51, 297-322. [CrossRef]

29. Karl, T.L. The Paradox of Plenty: Oil Booms and Petro-States; University of California Press: Oakland, CA, USA, 1997.

30. Collier, P.; Hoeffler, A. Greed and grievance in civil war. Oxf. Econ. Pap. 2004, 56, 563-595. [CrossRef]

31. Brunnschweiler, C.N.; Bulte, E.H. Linking Natural Resources to Slow Growth and More Conflict. Science 2008, 320, 616-617. [CrossRef] [PubMed]

32. Brunnschweiler, C.N.; Bulte, E.H. The resource curse revisited and revised: A tale of paradoxes and red herrings. J. Environ. Econ. Manag. 2008, 55, 248-264. [CrossRef]

33. World Bank. Expanding the Measure of Wealth: Indicators of Environmentally Sustainable Development; The World Bank: Washington, DC, USA, 1997; p. 1.

34. Giljum, S.; Eisenmenger, N. North-South Trade and the Distribution of Environmental Goods and Burdens: A Biophysical Perspective. J. Environ. Dev. 2004, 13, 73-100. [CrossRef]

35. Pérez-Rincón, M.A. Colombian international trade from a physical perspective: Towards an ecological "Prebisch thesis". Ecol. Econ. 2006, 59, 519-529. [CrossRef]

36. Moran, D.D.; Lenzen, M.; Kanemoto, K.; Geschke, A. Does ecologically unequal exchange occur? Ecol. Econ. 2013, 89, 177-186. [CrossRef]

37. Prell, C.; Feng, K.; Sun, L.; Geores, M.; Hubacek, K. The Economic Gains and Environmental Losses of US Consumption: A World-Systems and Input-Output Approach. Soc. Forces 2014, 93, 405-428. [CrossRef]

38. Weisz, H. Combining Social Metabolism and Input-Output Analyses to Account for Ecologically Unequal Trade. In Rethinking Environmental History: World-System History and Global Environmental Change; Hornborg, A., McNeill, J.R., Martinez-Alier, J., Eds.; Rowman Altamira: Lanham, MD, USA, 2007; pp. 289-306.

39. Dorninger, C.; Hornborg, A. Can EEMRIO analyses establish the occurrence of ecologically unequal exchange? Ecol. Econ. 2015, 119, 414-418. [CrossRef]

40. Hornborg, A.; Martinez-Alier, J. Ecologically unequal exchange and ecological debt. J. Political Ecol. 2016, 23, 328-333.

41. Dorninger, C.; Eisenmenger, N. South America's biophysical involvement in international trade: The physical trade balances of Argentina, Bolivia, and Brazil in the light of ecologically unequal exchange. J. Political Ecol. 2016, 23, 394-409.

42. Martinez-Alier, J.; Demaria, F.; Temper, L.; Walter, M. Changing social metabolism and environmental conflicts in India and South America. J. Political Ecol. 2016, 23, 467-491.

43. Schandl, H.; West, J. Material Flows and Material Productivity in China, Australia, and Japan. J. Ind. Ecol. 2012, 16, 352-364. [CrossRef]

44. Ekins, P.; Folke, C.; Costanza, R. Trade, environment and development: The issues in perspective. Ecol. Econ. 1994, 9, 1-12. [CrossRef] 
45. Muradian, R.; Martinez-Alier, J. Trade and the environment: From a "Southern"perspective. Ecol. Econ. 2001, 36, 281-297. [CrossRef]

46. World Bank. World DataBank. World Development Indicators; World Bank: Washington, DC, USA, 2016.

47. World Bank. World Bank GNI per Capita Operational Guidelines \& Analytical Classifications; World Bank: Washington, DC, USA, 2016.

48. Dittrich, M.; Bringezu, S. The physical dimension of international trade: Part 1: Direct global flows between 1962 and 2005. Ecol. Econ. 2010, 69, 1838-1847. [CrossRef]

49. Giljum, S. Trade, Materials Flows, and Economic Development in the South: The Example of Chile. J. Ind. Ecol. 2004, 8, 241-261. [CrossRef]

50. Muñoz, P.; Giljum, S.; Roca, J. The raw material equivalents of international trade. J. Ind. Ecol. 2009, 13, 881-897. [CrossRef]

51. Eurostat. Economy-Wide Material Flow Accounts (EW-MFA); Eurostat: Luxembourg, 2012.

52. Wiedmann, T.; Wilting, H.C.; Lenzen, M.; Lutter, S.; Palm, V. Quo Vadis MRIO? Methodological, data and institutional requirements for multi-region input-output analysis. Ecol. Econ. 2011, 70, 1937-1945. [CrossRef]

53. Weisz, H.; Duchin, F. Physical and monetary input-output analysis: What makes the difference? Ecol. Econ. 2006, 57, 534-541. [CrossRef]

54. Hubacek, K.; Giljum, S. Applying physical input-output analysis to estimate land appropriation (ecological footprints) of international trade activities. Ecol. Econ. 2003, 44, 137-151. [CrossRef]

55. Simoes, A.; Hidalgo, C. The Economic Complexity Observatory: An Analytical Tool for Understanding the Dynamics of Economic Development; Massachusetts Institute of Technology: Boston, MA, USA, 2016.

56. Kavoussi, R.M. Export expansion and economic growth. J. Dev. Econ. 1984, 14, 241-250. [CrossRef]

57. Sheehey, E.J. Exports and growth: A flawed framework. J. Dev. Stud. 1990, 27, 111-116. [CrossRef]

58. Hall, D. Land grabs, land control, and Southeast Asian crop booms. J. Peasant Stud. 2011, 38, 837-857. [CrossRef]

59. Brad, A.; Schaffartzik, A.; Pichler, M.; Plank, C. Contested territorialization and biophysical expansion of oil palm plantations in Indonesia. Geoforum 2015, 64, 100-111. [CrossRef]

60. Ribot, J.C.; Peluso, N.L. A theory of access. Rural Sociol. 2003, 68, 153-181. [CrossRef]

61. Backhouse, M. Green grabbing-The case of palm oil expansion in so-called degraded areas in the eastern Brazilian Amazon. In Political Ecology Agrofuels; Routledge: London, UK, 2014; pp. 167-184.

62. Pichler, M. Legal Dispossession: State Strategies and Selectivities in the Expansion of Indonesian Palm Oil and Agrofuel Production. Dev. Chang. 2015, 64, 508-533. [CrossRef]

63. Niewöhner, J.; Nielsen, J.Ø.; Gasparri, I.; Gou, Y.; Hauge, M.; Joshi, N.; Schaffartzik, A.; Sejersen, F.; Seto, K.C.; Shughrue, C. Conceptualizing Distal Drivers in Land Use Competition. In Land Use Competition; Niewöhner, J., Bruns, A., Hostert, P., Krueger, T., Nielsen, J.Ø., Haberl, H., Lauk, C., Lutz, J., Müller, D., Eds.; Springer International Publishing: Cham, Switzerland, 2016; Volume 6, pp. 21-40.

64. Einzenberger, R. Contested Frontiers: Indigenous Mobilization and Control over Land and Natural Resources in Myanmar's Upland Areas. Austrian J. South-East Asian Stud. 2016, 9, 163.

65. Kelly, A.B.; Peluso, N.L. Frontiers of Commodification: State Lands and Their Formalization. Soc. Nat. Res. 2015, 28, 473-495. [CrossRef]

66. Martinez-Alier, J. Social metabolism, ecological distribution conflicts, and languages of valuation. Capital. Nat. Soc. 2009, 20, 58-87. [CrossRef]

67. Brand, U.; Dietz, K. (Neo-)Extraktivismus als Entwicklungsoption? Zu den aktuellen Dynamiken und Widersprüchen rohstoffbasierter Entwicklung in Lateinamerika. Polit. Vierteljahresschr. 2014, 48, 133-170.

68. Gellert, P.K. Extractive Regimes: Toward a Better Understanding of Indonesian Development: Extractive Regimes. Rural Sociol. 2010, 75, 28-57. [CrossRef]

69. NFF to Hold Urgent Talks on Water Crisis. Syd. Morning Her. 2007. Available online: http:/ /www.smh.com. $\mathrm{au} /$ national/nff-to-hold-urgent-talks-on-water-crisis-20070419-8kj.html (accessed on 24 May 2017).

70. Gale, M.; Edwards, M.; Wilson, L.; Greig, A. The Boomerang Effect: A Case Study of the Murray-Darling Basin Plan. Aust. J. Public Adm. 2014, 73, 153-163. [CrossRef]

71. Auty, R.M. Natural resources, capital accumulation and the resource curse. Ecol. Econ. 2007, 61, 627-634. [CrossRef]

72. Burchardt, H.-J.; Dietz, K. (Neo-)extractivism-A new challenge for development theory from Latin America. Third World Q. 2014, 35, 468-486. [CrossRef] 
73. Staritz, C.; Gereffi, G.; Cattaneo, O. Shifting end markets and upgrading prospects in global value chains. Int. J. Technol. Learn. Innov. Dev. 2011, 44, 2.

74. Bridge, G. Global production networks and the extractive sector: Governing resource-based development. J. Econ. Geogr. 2008, 8, 389-419. [CrossRef]

75. Veltmeyer, $\mathrm{H}$. The political economy of natural resource extraction: A new model or extractive imperialism? Can. J. Dev. Stud. Rev. Can. D'études Dév. 2013, 34, 79-95. [CrossRef]

76. Buur, L.; Monjane, C.M. Elite capture and the development of natural resource linkages in Mozambique. In Fairness and Justice in Natural Resource Politics; Pichler, M., Staritz, C., Küblböck, K., Plank, C., Raza, W., Peyré, F.R., Eds.; Routledge: London, UK, 2017; pp. 200-217.

77. Pichler, M.; Staritz, C.; Küblböck, K.; Plank, C.; Raza, W.; Peyré, F.R. Fairness and Justice in Natural Resource Politics; Routledge/Taylor \& Francis Group: London, UK, 2016.

78. Martinez-Alier, J. The Environmentalism of the Poor: A Study of Ecological Conflicts and Valuation; Edward Elgar Publishing: Cheltenham, UK, 2003.

79. Kohl, B.; Farthing, L. Material constraints to popular imaginaries: The extractive economy and resource nationalism in Bolivia. Political Geogr. 2012, 31, 225-235. [CrossRef]

80. Andreucci, D.; Radhuber, I.M. Limits to "counter-neoliberal" reform: Mining expansion and the marginalisation of post-extractivist forces in Evo Morales's Bolivia. Geoforum 2015, in press. [CrossRef]

81. Pichler, M. What's democracy got to do with it? A political ecology perspective on socio-ecological justice. In Fairness and Justice in Natural Resource Politics; Pichler, M., Staritz, C., Küblböck, K., Plank, C., Raza, W., Peyré, F.R., Eds.; Routledge/Taylor \& Francis Group: London, UK, 2016; pp. 33-51.

82. Brand, U.; Dietz, K.; Lang, M. Neo-Extractivism in Latin America-one side of a new phase of global capitalist dynamics. Cienc. Política 2016, 11, 125-159. [CrossRef]

83. Economist Tata Steel: Cast-Iron Arguments. Economist 2016. Available online: http://www.economist. com/news/leaders/21696527-how-should-governments-cope-global-glut-steel-britain-depressing-case (accessed on 24 May 2017).

84. Economist Global Steel: Through the Mill. Economist 2016. Available online: http://www.economist.com/ news/business / 21696556-it-hard-see-future-many-worlds-high-cost-steel-producers-britains-are-no (accessed on 24 May 2017).

(C) 2017 by the authors. Licensee MDPI, Basel, Switzerland. This article is an open access article distributed under the terms and conditions of the Creative Commons Attribution (CC BY) license (http:/ / creativecommons.org/licenses/by/4.0/). 